\title{
IV Simpósio Binacional de Polímeros Argentino-Chileno/ Archipol IV, Vina del Mar, 2007
}

Este simpósio, chamado Archipol, reúne as comunidades poliméricas da Argentina e do Chile a cada dois anos desde 2001, alternando os países. Este último foi realizado na praia de Reñaca, na cidade de Viña del Mar no litoral Chileno no período de 2 a 5 de dezembro de 2007. Foi organizado por um grupo de professores da Pontifícia Universidad Católica de Chile, liderados pelo Prof. Deodato Radic. O comitê científico foi constituído de 17 professores da Argentina e do Chile. O evento ocorreu no hotel Conference Town de Reñaca, que conta com um excelente centro de eventos com um grande auditório e salas menores. $\mathrm{O}$ congresso teve 120 participantes que apresentaram 11 conferências plenárias, 40 comunicações orais de 20 minutos e e dois brasileiros (Osvaldo Oliveira Jr, Chu, Denise Freitas Petri) e uma pelo Prof. Lennard Piculel que, embora tenha nascido no Brasil, trabalha e reside na Suécia. Entre os participantes havia um grande contingente de argentinos e alguns representantes dos outros países de língua espanhola da América Latina, como Colômbia, México e Venezuela. Do Brasil havia mais dois participantes, além dos conferencistas convidados. De um modo geral os trabalhos apresentados eram mais direcionados para a físico-química de polímeros e a síntese de copolímeros e todos de muito bom nível científico. Houve uma participação muito grande de alunos de pós-graduação, que representavam aproximadamente $50 \%$ dos participantes. Deve-se ressaltar que

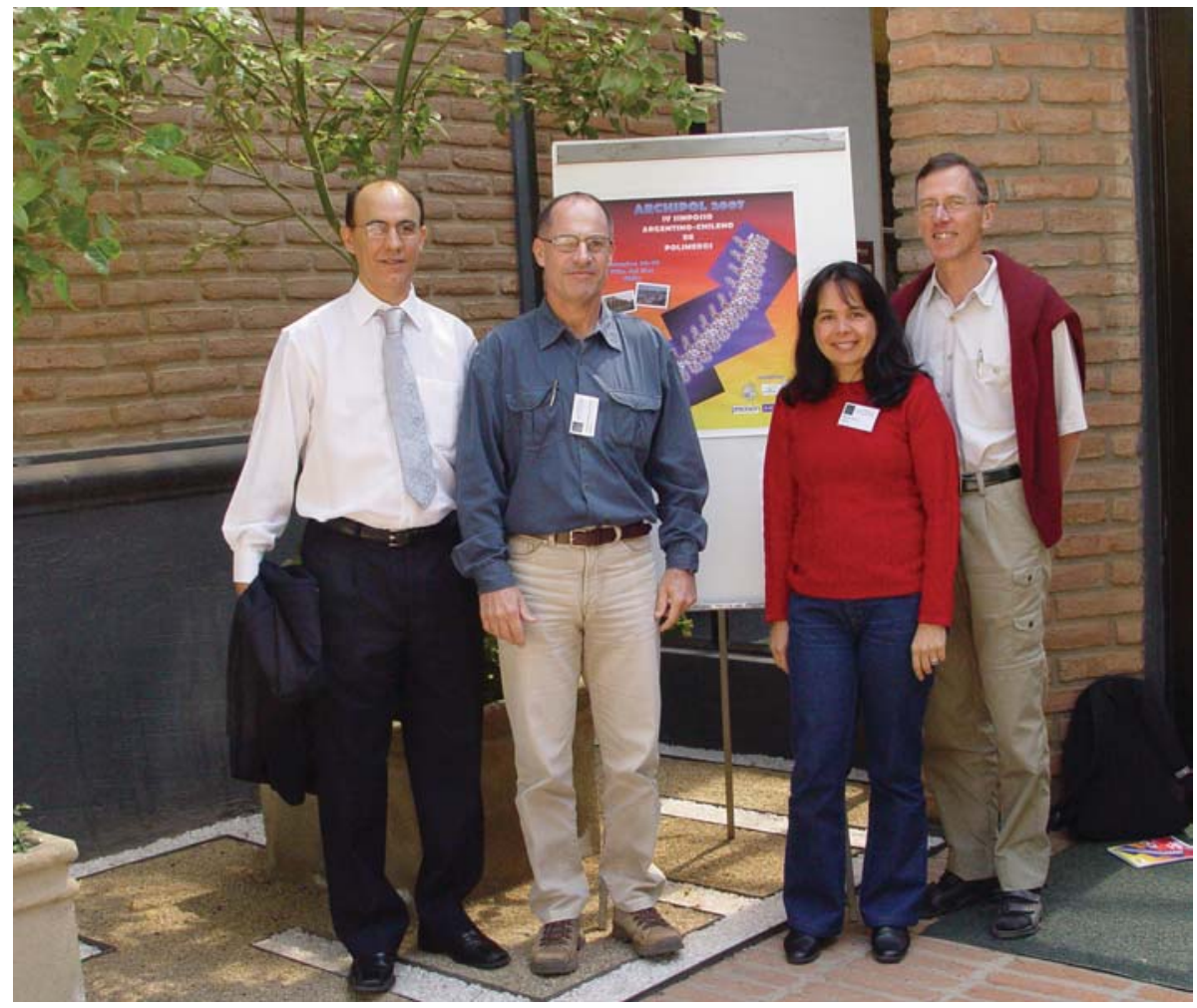

Da esquerda: Prof. Dr. Osvaldo Oliveira Jr. (USP - São Carlos/SP), Prof. Dr. Marco-Aurelio De Paoli (UNICAMP/IQ), Prof. Dra. Denise Freitas Petri (USP - São Paulo/SP) e Prof. Lennart Piculel (nascido no Brasil) da Universidade de Lund, Suécia.

125 painéis. Havia duas conferencias plenárias pela manhã e duas a tarde, seguidas de duas sessões paralelas de comunicações orais. As sessões de painéis foram realizadas no final da tarde com uma simultânea degustação de vinho, o que garantia a presença de todos. As conferências plenárias foram proferidas por pesquisadores chilenos, argentinos, espanhóis, um sueco, um italiano, um grego, dois franceses as sessões do congresso estavam sempre cheias, inclusive a sessão da manhã do último dia. Com relação à parte social, no dia 4 houve um jantar em Valparaiso em um hotel panorâmico e um almoço de encerramento no dia 5/12. O próximo será organizado pelos argentinos, provavelmente na localidade de Los Cocos na região montanhosa da província de Córdoba.

Matéria elaborada pelo Prof. Dr. Marco-Aurelio De Paoli, Unicamp/IQ 